\title{
Potential for leasing institutional lands in Windham County, Connecticut: Toward A New England Food Vision
}

\author{
Mary L. Buchanan* \\ University of Connecticut
}

Submitted October 11, 2019 / Revised January 7, February 10, and April 26, 2020 /

Accepted April 26, 2020 / Published online July 27, 2020

Citation: Buchanan, M. L. (2020). Potential for leasing institutional lands in Windham County, Connecticut: Toward A New England Food Vision. Journal of Agriculture, Food Systems, and

Community Development, 9(4), 245-257. https://doi.org/10.5304/jafscd.2020.094.018

Copyright (C) 2020 by the Author. Published by the Lyson Center for Civic Agriculture and Food Systems. Open access under CC-BY license.

\begin{abstract}
The social and environmental impacts of the modern industrial food system are ample reason to explore alternative scenarios. A New England Food Vision calls for building a resilient food system at the regional scale, with the goal of providing $50 \%$ of New England's food from within the region by the year 2060. Land access is a substantial challenge for aspiring farmers, particularly those from socially marginalized groups. Leasing farmland is less expensive than purchasing it outright, although not without its challenges. Institutionally owned land-properties owned by government entities, nonprofit organizations, educational organizations, religious organizations, or healthcare organizations - may be especially suitable for leasing to aspiring farmers due to their secure tenure and reduced development pressure. This site suitability
\end{abstract}

* Mary L. Buchanan, Doctoral Candidate, Department of Geography, University of Connecticut; +1-203-430-5113; mary.buchanan@uconn.edu analysis identifies institutionally owned lands in Windham County, Connecticut, excludes areas containing ecological or practical constraints, and assesses the new farmland acreage and food production that might be generated if these lands were converted to agricultural cultivation. Leasing the resulting lands to farmers would increase the agricultural acreage within the county by almost $19 \%$. The majority of the land identified was owned either by state or municipal government entities, so farmer advocate organizations seeking to promote leasing arrangements should tailor their resources to this type of land ownership and audience.

\section{Keywords}

Scenarios, Alternative Landscape Futures, New England, Agriculture, Geography, New England Food Vision, Land Use

\section{Funding Disclosure}

The author is grateful for support from the University of Connecticut Doctoral Program in Geography. 


\section{Introduction}

\section{The Industrial Food System and the Growing Response}

Agriculture in the United States has largely become an industrial endeavor, as crops and livestock are produced at massive scales and large corporations control many of the links along the chain of production. The byproducts of this system include environmental degradation, public health crises, dangerous labor conditions, increased emissions of greenhouse gases, land loss among small farmers, and countless other social justice and sustainability concerns, many of which intersect each other. For example, the widespread use of pesticides and chemical fertilizers contributes to air and water pollution while simultaneously affecting farmworker health (Horrigan, Lawrence, \& Walker, 2002), and large-scale livestock production requires vast monocultures of grain for feed and results in the use of antibiotics that may ultimately contribute to antibiotic resistance in humans (Horrigan et al., 2002). Consolidation of food production onto large mechanized farms can drive smaller producers out of business and negatively affect rural communities (Horrigan et al., 2002; Redlin \& Redlin, 2003). The social costs of this system are borne disproportionately by already marginalized peoples, evidenced by the loss of Black-owned farms due to discriminatory lending and government assistance programs (Green, Green, \& Kleiner, 2011), meager wages for immigrant farmworkers who produce the nation's food even as they themselves go hungry (Brown \& Getz, 2011), and a lack of access to fresh produce and retailers of nutritious food in poorer urban areas (McClintock, 2011). There are many, many reasons for concern.

In response to the substantial detriments of an increasingly globalized industrial-scale agricultural system, many scholars and activists have called for a shift to more localized food systems. A single satisfactory definition of "local" may not be possible, or even desirable. There is no agreed-upon distance or characteristic, although often the presence of direct-to-consumer marketing channels like farmers markets and farm stands is a signifier (Low et al., 2015). Feagan (2007) points out that the oft-cited "binary between the local and the global" (p. 34) is overly simplistic and contends that conceptions of local must necessarily change depending on a case's particular circumstances. Schnell (2013) likewise argues that the local food movement consists of many overlapping and placebased projects that cannot be adequately confined within a single definition of local. Within the field of geography, scale is often recognized as a socially constructed concept rather than an a priori truth or geographic distance (Born \& Purcell, 2006; Neumann, 2009; Zimmerer \& Bassett, 2003).

Further muddying the waters are the qualitative values often automatically associated with local food systems. Feagan calls attention to how frequently notions of "embeddedness" are mentioned within local food systems literature, highlighting the social and cultural relationships surrounding food transactions at a community scale (Feagan, 2007). Many advocates for local food systems, it seems, are not only hoping for a shorter chain from producer to consumer; many are invested in building values like trust, tradition, and a renewed sense of place (Feagan, 2007)—all worthy goals but harder to quantify, standardize, and implement.

Born and Purcell (2006) caution against falling into the "local trap" by assuming that locally scaled agriculture will inherently be free of social injustice and unsustainable practices, arguing that these qualities are not inherently guaranteed at any particular scale. In their eyes, re-localization efforts must consciously incorporate social justice and sustainability dimensions into their new alternative food systems or else risk perpetuating the same problems at a different scale (Born \& Purcell, 2006). Agyeman (2013) likewise reminds us that "diversity and deeply unequal power relations exist within any given locality" (p. 64) and that attention must always be paid to who is empowered or disempowered by localization. By centering the achievement of justice and sustainability as the goal of alternative food movements, rather than the local scale itself, the local trap can be avoided. However, definitions of "justice" and "sustainability" are likewise subject to dispute and vary depending on one's values and what sort of future one hopes to see (Hassanein, 2003; Miller et al., 2014).

The problem is multifaceted, pervasive, and 
unlikely to be neatly resolved. However, Sen (2008) suggests that a neat resolution is not a useful objective, calling attention to the "comparative question" (p. 336) of justice and arguing that it is better to focus on improvement rather than perfection. Sen also notes that the actual choices available tend to be between non-ideal alternatives, and spending time debating the ideal state will not necessarily help make choices in practice (Sen, 2012). When it comes to the current industrial food system, the social, health, and environmental costs are steep enough that an alternative framework may offer real relief, even if imperfectly defined.

\section{Arguments for Regionalization, and A New} England Food Vision

Regionalism may be one such framework. Ruhf (2015) argues that regionalism, defined as "a framework for economic, policy, and program development that responds to regional characteristics, differences, and needs and encourages regional approaches and solutions," (p. 651) can increase the resiliency of food systems and provide a context for addressing environmental and social concerns. The familiar problem of loose definitions is encountered here as well. Ruhf is careful to note that a regional food system is not just a collection of smaller-scale local food systems, but rather includes and extends beyond the local to operate at a broader scale (Ruhf, 2015; Ruhf \& Clancy, 2010); collaboration among small food producers to aggregate their products and sell to larger markets, like institutions and wholesale retailers, is one such example (Low et al., 2015). The U.S. Department of Agriculture Economic Research Service acknowledges the blurred lines between local and regional, choosing instead to refer to both together as "place-specific clusters of agricultural producers of all kinds-farmers, ranchers, fishers—along with consumers and institutions engaged in producing, processing, distributing, and selling foods" (Low et al., 2015, p. 1). Regions may be political, biophysical, or cultural/social (e.g., counties, watersheds, or "the Gold Coast" of Connecticut), and may have flexible boundaries, sometimes overlapping with other regions or containing nested subregions (Ruhf, 2015; Ruhf \& Clancy, 2010). Many regions include both urban and rural areas, and the interplay between these is particularly relevant for questions of food need, food production capacity, and transport distance, as Peters, Bills, Lembo, Wilkins, and Fick (2008) examined when they mapped potential "foodsheds" for population centers in the state of New York. A successful regional food system would be multiscalar and flexible, meeting as much of its population's food, economic, and social needs as possible without claiming full self-sufficiency (Ruhf \& Clancy, 2010). This regional framework, although inevitably nebulous, avoids the rigid localglobal dichotomy and offers an option for increasing local self-reliance without shutting down connections to the wider world.

Additionally, Griffin, Conrad, Peters, Ridberg, and Tyler (2014) suggest that increasing regional self-reliance in the food system can help to decrease vulnerability to disruptions caused by climate change-in contrast to a system that concentrates food production for the nation in areas likely to experience climate impacts, like California. Coordination among local food producers across a region may also increase the economic viability of small-scale producers by presenting opportunities to reach broader markets and supply larger consumer institutions; the increasing prevalence of regional food hubs supports this claim (Berti \& Mulligan, 2016; Low et al., 2015).

Ruhf (2015) argues that New England is "an ideal learning laboratory" (p. 651) for exploring regional food system possibilities. The six New England states share a strong regional identity, a history of multistate collaboration, and a set of similar strengths and challenges when it comes to food production (Ruhf, 2015). Multiple regionwide initiatives, including Food Solutions New England and the New England Farm and Food Security Initiative crafted by the New England Governors Conference, have already emerged as New Englanders attempt to steer their food system in a more regionalized direction. Additionally, farmland preservation programs, now common across the nation, were pioneered in New England, and the region currently has the most farm-to-consumer direct sales in the United States (Ruhf, 2015); both trends suggest a potential leadership role for the 
region in setting an example of strong food system policies and practices.

A New England Food Vision (Donahue et al., 2014) was published by a team of scholars, experts, and activists in 2014, as part of a collaboration between Food Solutions New England and the University of New Hampshire. These authors imagine a future food system for New England guided by four central values: access to food for all, healthy diets for all, sustainable food production, and thriving communities (Donahue et al., 2014). Like Ruhf, Donahue et al. see the potential for a robust regional food system to play a critical role in achieving social and environmental well-being in New England. Together with these holistic goals, the vision calls for increasing New England's regionally produced food to $50 \%$ (up from approximately $12 \%$ currently) of its population's needs by 2060 (Donahue et al., 2014).

\section{Agricultural Opportunities}

Given the current level of geographic and corporate concentration of farmland (Griffin et al., 2014), achieving this goal in New England will require bringing some non-agricultural land into active cultivation. Donahue et al. (2014) estimate that agricultural land in New England will have to increase from approximately 2 million acres $(809,000$ hectares, $5 \%$ of the region's land cover) to 6 million acres $(2,428,000$ ha, $15 \%$ of the region's land cover) in order to meet $A$ New England Food Vision's target. Advances in hydroponics and vertical farming - and financial support for these initiatives - might reduce some of the need for literal farmland, but undoubtedly the amount of actual land converted to agriculture would be considerable. The vision does not identify specific lands to be converted, nor does it prescribe specific strategies for subregions within New England, although the needed land use changes typically are decided by policy at a much narrower scale in piecemeal fashion. Anderson (2019) highlights the importance of crafting visions for a more sustainable food system future at multiple scales, which suggests the value of conducting narrower scenario visioning within the larger New England vision. To carry out this transition thoughtfully at these reduced scales, which are more conducive to implementing on-the-ground change, it would be useful to identify beforehand the lands most suitable for new or renewed agricultural cultivation. Erickson, Lovell, and Méndez (2013) provide a useful term for these types of lands: "agricultural opportunities."

Efforts to identify agricultural opportunities have become somewhat common in urban settings, where food insecurity and a lack of access to green spaces have helped to drive a wave of interest in creating community gardens. Colasanti and Hamm (2010) mapped publicly owned vacant land in Detroit, Michigan, and modeled potential crop yields from these lands; McClintock, Cooper, and Khandeshi (2013) followed a nearly identical approach for vacant and underutilized public land in Oakland, California. Kremer and DeLiberty (2011) analyzed high resolution aerial imagery of Philadelphia, categorizing land cover based on maximum likelihood classification, and identifying areas with grass or bare soil in residential yards that could be easily converted to agriculture. Many of these researchers worked in conjunction with local stakeholders like government officials, nonprofit organizations, and urban farmers. The emphasis of these studies tends to be the geographical inventory, or the "supply-consumption perspective" (Colasanti \& Hamm, 2010), with less attention paid to who might do the proposed future farming and how they might access the land.

In urban areas where much of the land is developed, agricultural opportunities are often heavily determined by where pockets of vacant land remain, often in publicly owned parks or lots. In contrast, Erickson et al. (2013) provide an example of an analysis where agricultural opportunities are identified on privately owned lands in Chittenden County, a mostly rural county in Vermont. With more undeveloped land to choose from, Erickson et al. selected agricultural opportunities based on land cover, soil, and slope, while also considering neighborhood clusters and proximity to potential consumer markets like the city of Burlington. Finding many of these sites within residential parcels, often near existing agricultural land, Erickson et al. ultimately determined that Chittenden County had enough viable land area to produce most of its population's food 
needs, including vegetables, hard wheat, and fodder for beef and pork production. Although most counties are not seeking to feed their populations from solely within county boundaries, the potential for increased local production is still promising.

\section{The Challenge of Land Access and the Argument for Leasing Institutional Land}

For farmers, identifying cultivable land is only the beginning; accessing this land is a major challenge, particularly for aspiring farmers in New England (Bowell, Coffin, \& Martin, 2011; Land for Good, 2012). The American Farmland Trust lists four requirements for potential farmland: the land must be available in an adequate size, affordable for the aspiring farmer, appropriate for cultivation, and securely held (American Farmland Trust, 2015). Finding land that meets these criteria is a challenge, particularly in terms of affordability and security of tenure.

Land discrimination has a long history in the United States, leading to a series of lawsuits against the United States Department of Agriculture by Black farmers, women farmers, American Indian farmers, and Hispanic American farmers, as well as resulting disparities in agricultural land ownership that persist to this day (Carter, 2017; Green, Green, \& Kleiner, 2011; Parsons et al., 2010). With no inherited family land, limited capital, and a legacy of lacking support, aspiring farmers who are lowincome, young, or otherwise disadvantaged face significant financial obstacles to becoming landowners.

For those who cannot afford to purchase land outright, leasing land offers an alternative. Leasing is imperfect; the possibility of landowners changing their minds or failing to renew the arrangementespecially if the landowner is a private individual who might experience familial or financial changes -makes it risky for farmers to invest in ecological improvements to the land or long-term plans for their business (Hachmyer, 2017). However, land owned by state governments, municipalities, land trusts, churches, schools, and other nonprofit institutions may hold less risk for farmers due to the steady ownership and decreased development pressure. Additionally, institutions may be encouraged to lease land at a sliding scale or graduated rate, particularly if their institutional missions support local agriculture, as some municipal plans of conservation and development do (Land for Good, 2012). Churches and schools may have affiliated communities that would benefit from local produce or the educational experience of gardening, providing more incentives to partner with a leasing farmer. Thus, the criteria of affordable access and secure tenure can be fulfilled while the arrangement also provides benefits to the landowner (Bowell et al., 2011). Furthermore, there is precedent for these types of leasing arrangements and existing resources to guide their creation and maintenance. The community land trust movement has demonstrated one model for nonprofit ownership of land with long-term leases to individuals, most often for the purposes of providing affordable housing options (Gray, 2008; Meehan, 2014), and organizations like American Farmland Trust and Land for Good have released handbooks for facilitating leasing arrangements with farm operations specifically (Bowell et al., 2011; Land for Good, 2012). This combination of encouraging factors and the consequent potential for future farmland on institutionally owned lands form the basis of this analysis, which utilizes a site suitability approach to identify agricultural leasing opportunities at a county scale in pursuit of the goals of A New England Food Vision.

\section{Methods}

\section{Study Area}

Windham County is located in the northeast corner of Connecticut and comprises 15 towns. It is known colloquially as "The Quiet Corner" for its mostly rural setting and low population density. A large portion of Windham County is also considered part of "The Last Green Valley," a 35-town Natural Heritage Corridor designated by Congress in 1994 that runs through eastern Connecticut into south-central Massachusetts (The Last Green Valley, Inc., 2010). The county thus may be considered both a political region corresponding to recognized boundaries, and a cultural region corresponding to the Quiet Corner and Last Green Valley designations, to use Ruhf (2015)'s terminology. In 2010, according to land cover data from the University of 
Connecticut Center for Land Use Education and Research (CLEAR), there were 34,156.05 acres $(13,822.46 \mathrm{ha})$ of land in agricultural use within the county, including crop production, active pasture, and/or abandoned fields that have not yet become covered in woody vegetation (Figure 1). The per-capita income in Windham County was US $\$ 31,106$ in 2018, approximately three-fourths of the per capita income of the state of Connecticut as a whole (U.S. Census Bureau, 2018). Almost 12\% of county residents live below the poverty line (U.S. Census Bureau, 2018). Windham County has the highest levels of child food insecurity in Connecticut, with $16.4 \%$ of children in the county categorized as food-insecure in 2017 (Feeding America, 2019).

\section{Data}

Parcel shapefiles for the towns in Windham County were acquired from the University of Connecticut Map and Geographic Information Center (MAGIC), the Northeastern Connecticut Council of Governments (NECCOG), and in some cases the towns themselves. Landowner information for each parcel was acquired from NECCOG or from the tax assessor offices in individual towns. Land cover data, including a data layer identifying "core forests" (contiguous forest areas more than $300 \mathrm{ft}[91 \mathrm{~m}]$ from any forest/nonforest edge), were acquired from CLEAR, in raster format with a cell size of $30 \mathrm{~m}$. Shapefiles indicating the locations of ecological constraint variables were acquired from the Connecticut Department of Energy and Environmental Protection (DEEP), and included inland wetlands and hydric soils, natural diversity database areas (areas identified by the state as containing species of conservation concern or significant natural communities), critical habitat areas (areas identified by the state as containing rare and specialized wildlife habitat), water bodies, and highly erodible soils.

All geospatial analysis was completed using ArcGIS 10.6.1 and the ModelBuilder interface, within the

NAD_1983_StatePlane_Connecticut_FIPS_0600_ Feet coordinate system.
Figure 1. Windham County in the State of Connecticut

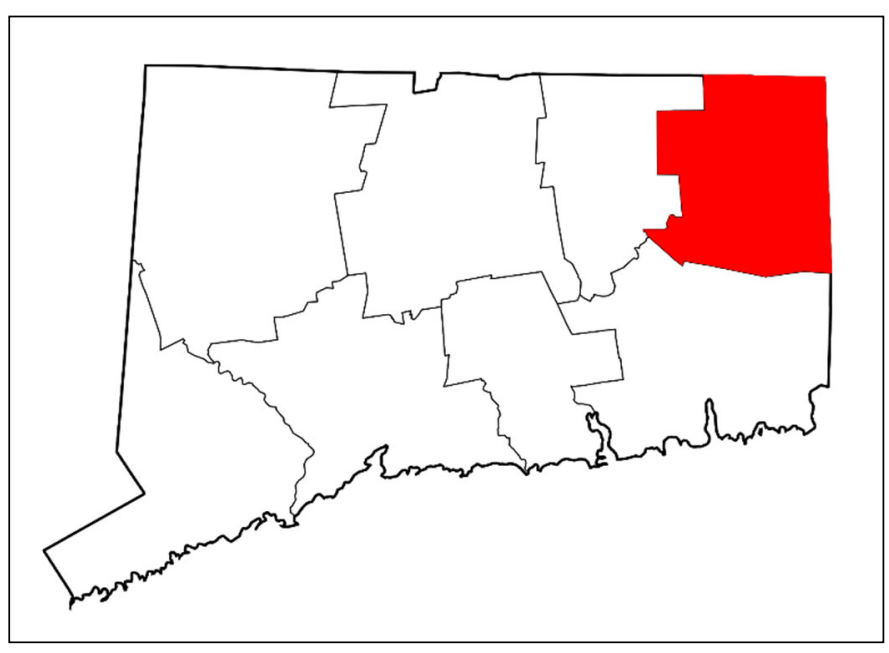

\section{Identifying Institutional Lands and Incorporating} Constraints

The "institutional lands" considered here broaden the potential pool of agricultural opportunities beyond the "public" lands considered by Colasanti and Hamm (2010) and McClintock, Cooper, and Khandeshi (2013). Institutionally owned parcels were identified through landowner information by selecting all parcels containing any of the following keywords in the ownership attribute table: "town," "land trust," "church," "parish," "school," "university," “college," “synagogue," “fellowship," "community," "health," "hospital," "state of Conn," "Connecticut, State of," and "Joshuas" (the name of a well-known local land trust). The resulting selected parcels were further categorized by institution type. Parcels containing the keywords "town," "state of Conn," or "Connecticut, State Of" were categorized as owned by government entities. Parcels containing the keywords "land trust," "Joshuas," or "community" were categorized as owned by non-profit community organizations. Parcels containing the keywords "church," "parish," "synagogue," or "fellowship" were categorized as owned by religious organizations. Parcels containing the keywords "school," "university," or "college" were categorized as owned by educational institutions. Parcels containing the keywords "health" or "hospital" were categorized as owned by healthcare institutions. Each town's selected parcel layer was manually checked for discernible errors, such as private 
landowners sharing a name with a keyword, properties with attribute information indicating they contained cemeteries or housing developments, or parcels that were visually identifiable as roads; these parcels were all removed from the selection.

A land cover data layer from CLEAR was overlaid onto the parcel selection layer to remove all areas that are already under agricultural use (as this project focuses on new farmland) as well as all areas already classified as "developed" (as the costs of restoring this land to cultivation will likely be prohibitive).

Ecological constraint variables were then overlaid with the parcel selection layer. In order to reduce the ecological impact of the proposed future farmland, all areas overlapping with inland wetlands, hydric soils, core forest areas, highly erodible soils, critical habitats, and natural diversity areas (as mapped by the Connecticut DEEP) were removed from consideration. All land within $50 \mathrm{ft}(15 \mathrm{~m})$ of a body of water was also removed, as the Connecticut Manual of Best Management Practices for Agriculture recommends leaving a riparian buffer zone of at least $50 \mathrm{ft}(15 \mathrm{~m})$ between agricultural land and bodies of water in order to protect water quality (Holbrook, 1996). It is worth noting that the lands excluded here for ecological reasons are delineated mostly by state-defined metrics, and so are limited by the methodology and value systems of state agencies. However, this approach has the advantage of being relatively simple to convey to public stakeholders without a scientific background and will be easier to integrate with existing state policy. Any specific parcels identified in this analysis would need to be ground-truthed prior to enacting any land use change, as shapefiles are not without error and land conditions vary over time.

After all constraints were removed, ArcMap's "Calculate Geometry" Tool was used to calculate the acreage of the remaining selected areas in each town, which were further delineated by institutional category type.

\section{Estimating Future Food Production and} Agricultural Footprints

Crop yield per acre will naturally depend on the type of crop planted and the method of cultivation.
These decisions, in turn, depend on climate and land suitability as well as consumer demand. The type of food system possible in New England's future, then, will be contingent upon what future New Englanders choose to eat-no amount of local farmland cultivation will suffice if every New Englander wants to dine on tropical fruit every day. A New England Food Vision sketches out three different possible diet scenarios for New Englanders: the Current Diet, the Omnivore's Delight Diet, and the Regional Reliance Diet, all of which would require different agricultural production patterns (Donahue et al., 2014). The Current Diet represents an extension of New England's present food consumption, in which approximately a quarter of calories consumed are from meat, fish, and eggs, with added fats counting for nearly $20 \%$ more, and less than $10 \%$ of calories coming from fruits, vegetables, and whole grains combined (Donahue et al., 2014). Under these current trends, the percentage of New England's food produced within the region will remain around $12 \%$. The Omnivore's Delight Diet derives only $15 \%$ of calories from meat, fish, and eggs, reduces the percentage from added fats, and increases fruit, vegetable, and whole grain consumption (Donahue et al., 2014). This diet aligns with Donahue et al.'s target goal of being able to produce $50 \%$ of the region's food within New England. The Regional Reliance Diet, which imagines a future of greater scarcity where nearly $70 \%$ of New England's food must come from within the region, further reduces meat, fish, and eggs, removes imported warm-climate fruit completely, and increases the calories derived from protein-rich plants (Donahue et al., 2014). For each of these diet scenarios, the per capita agricultural footprint calculated by Donahue et al. was used to calculate the number of people who could be fed from the acreage identified in the site suitability analysis for Windham County.

\section{Results}

The site suitability analysis identified 6,343.27 acres (2,567.03 ha) of suitable institutionally owned agricultural land across Windham County, an increase of $18.57 \%$ from 2010 agricultural acreage (Table 1 and Figure 2). Potential acreage increases and percentage increases varied greatly by town 
(Table 1 and Figure 3), with an average increase of 422.88 acres (171.13 ha) and a median increase of 476.46 acres (192.82 ha). Of the identified acres, nearly three-fourths are held in government ownership by either the state of Connecticut or individual municipalities; educational organizations own much of the remainder, followed by land trusts, religious organizations, and health care organizations (Figure 4).

According to Donahue et al.'s (2014) estimate for an extension of New England's current diet, each New Englander will have a per capita agricultural footprint of 1.10 acres ( $0.45 \mathrm{ha})$; under this scenario, the added institutional land would be able to supply food for 5,767 additional people. The Omnivore's Delight scenario has a per capita agricultural footprint of 0.67 acres $(0.27 \mathrm{ha})$ (Donahue et al., 2014), and so the institutional land would be able to feed 9,468 additional people. The Regional Reliance scenario has a per capita agricultural footprint of 0.6 acres (0.24 ha) (Donahue et al., 2014), and so the institutional land would be enough to feed 10,572 people under this scenario. The U.S. Census population estimate for
Windham County in 2018 was 117,027 people

(U.S. Census Bureau, 2018).

\section{Discussion}

Leasing land, although often more feasible for aspiring farmers than purchasing land, is not without its unique challenges. Farmers and the landowners they rent from may have differing expectations or personality conflicts, and shortterm leases may disincentivize agricultural practices that require longer-term investment (Hachmyer, 2017). These challenges are particularly acute when they are reinforced by the American attachment to the principle of private property. Hachmyer (2017) cautions that focusing on expanding access to rentable land without a community-level approach may serve only to further entrench a system in which farmers (and the food system they create) are always at risk of losing the land they cultivate, a concern that echoes Donahue's (2003) earlier urging that the agrarian landscape be protected through community ownership. The focus on institutional lands in this analysis is meant to offer a geographic pathway toward the community-level

Table 1. Potential Increases in Agricultural Acreage From Converting Institutional Land in Windham County Institutional lands are categorized by the following ownership types: government, nonprofit, religious organization, educational institution, and healthcare institution.

\begin{tabular}{|c|c|c|c|c|c|c|c|c|}
\hline \multirow[b]{2}{*}{ Town } & \multirow{2}{*}{$\begin{array}{c}\text { Agricultural } \\
\text { Acres (2010) }\end{array}$} & \multicolumn{5}{|c|}{ Potential Acres by Type of Institutional Land } & \multirow{2}{*}{$\begin{array}{l}\text { Total Potential } \\
\text { Acreage }\end{array}$} & \multirow{2}{*}{$\begin{array}{l}\text { Total \% } \\
\text { Increase }\end{array}$} \\
\hline & & Government & Nonprofit & Religion & Education & Health & & \\
\hline Woodstock & $6,232.43$ & 300.23 & 149.70 & 3.77 & 42.43 & 0.00 & 496.13 & 7.96 \\
\hline Thompson & $2,364.59$ & 300.46 & 72.47 & 27.02 & 70.74 & 7.30 & 477.99 & 20.21 \\
\hline Eastford & $1,297.19$ & 42.47 & 4.72 & 4.46 & 388.07 & 0.00 & 439.72 & 33.90 \\
\hline Ashford & $1,754.09$ & 335.70 & 52.77 & 52.85 & 286.38 & 0.00 & 727.70 & 41.49 \\
\hline Putnam & 911.58 & 204.92 & 23.10 & 7.03 & 0.04 & 22.32 & 257.41 & 28.24 \\
\hline Pomfret & $4,401.21$ & 334.09 & 127.37 & 9.41 & 219.73 & 0.00 & 690.60 & 15.69 \\
\hline Killingly & 1,339.66 & 212.83 & 0.00 & 29.31 & 0.87 & 1.51 & 244.52 & 18.25 \\
\hline Chaplin & 636.30 & 465.67 & 6.65 & 4.14 & 0.00 & 0.00 & 476.46 & 74.88 \\
\hline Hampton & $1,595.58$ & 579.82 & 28.78 & 0.18 & 0.00 & 0.00 & 608.78 & 38.15 \\
\hline Brooklyn & $2,299.20$ & 162.42 & 0.15 & 32.35 & 2.58 & 0.00 & 197.50 & 8.59 \\
\hline Sterling & $1,685.17$ & 540.57 & 0.44 & 0.28 & 0.00 & 0.00 & 541.29 & 32.12 \\
\hline Plainfield & $3,248.66$ & 539.07 & 19.23 & 12.12 & 0.51 & 2.03 & 572.96 & 17.64 \\
\hline Canterbury & 2,911.18 & 82.19 & 2.74 & 6.35 & 33.61 & 0.00 & 124.89 & 4.29 \\
\hline Windham & $1,487.98$ & 256.15 & 18.05 & 2.88 & 1.51 & 3.25 & 281.37 & 18.91 \\
\hline Scotland & $1,991.22$ & 174.94 & 20.29 & 10.72 & 0.00 & 0.00 & 205.95 & 10.34 \\
\hline Full County & $34,156.05$ & $4,531.54$ & 526.46 & 202.87 & $1,046.47$ & 36.41 & $6,343.27$ & 18.57 \\
\hline
\end{tabular}

Note: 1 acre $=0.40$ hectare 
approach that Hachmyer and Donahue call for, under the broader scope of $A$ New England Food Vision's requirement for new land to be brought into cultivation. Although this case study models this approach within Windham County, Connecticut, the methodology can be applied at other scales and in other regions if parcel ownership data and land cover data can be acquired, since, certainly, the challenge of land access for aspiring farmers is not unique to New England.

The vast majority of institutionally owned lands identified through this analysis are government-owned at either the state or municipal level; therefore, efforts to promote agricultural leasing are likely to have the greatest impact when targeted to state and local land use policymakers. There is potential for convergence between this goal and

\section{Figure 2. Institutionally Owned Lands in Windham County Identified by} Site Suitability Analysis with Constraints Excluded

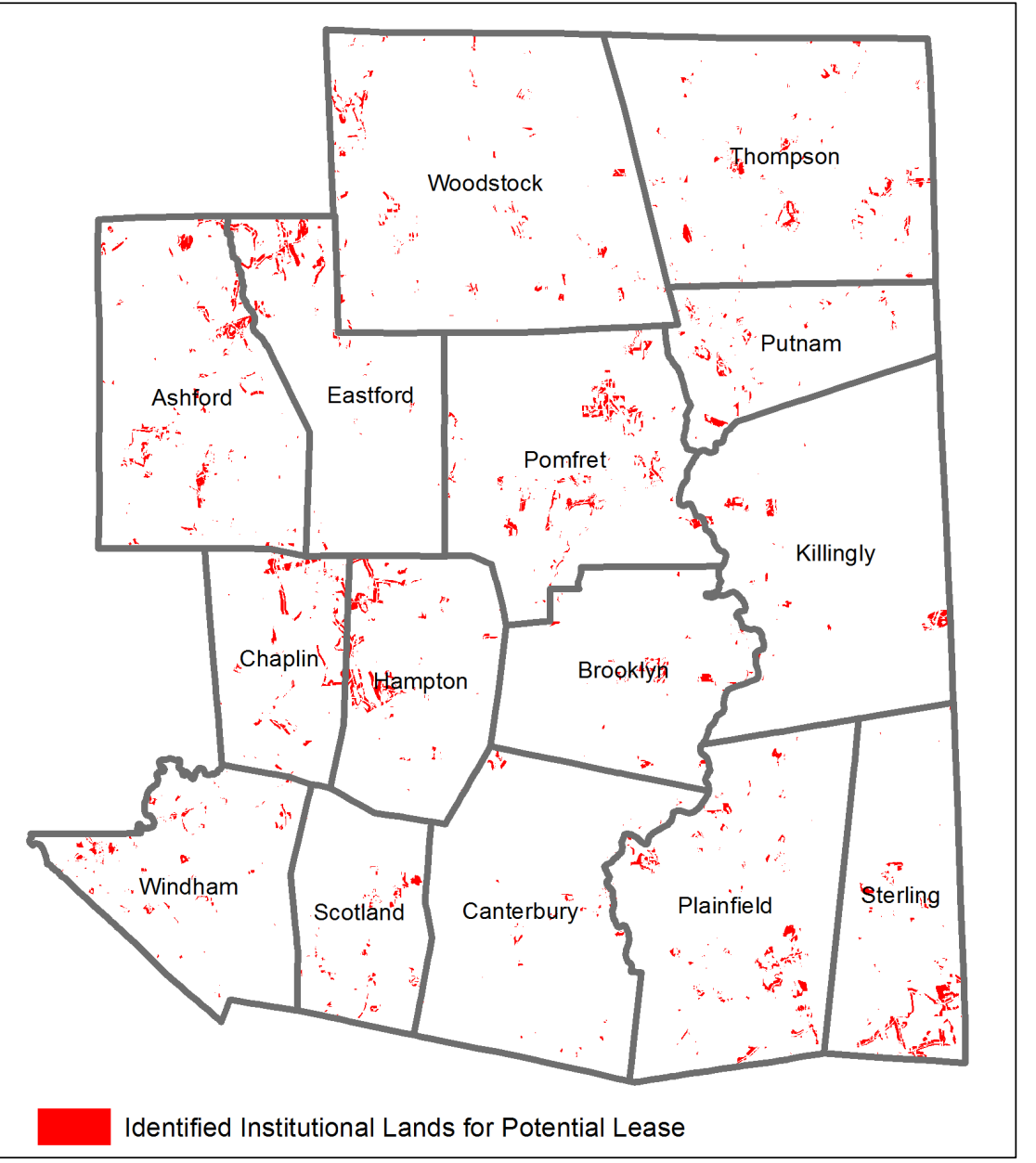

existing government objectives. The Connecticut State Department of Agriculture coordinates the CT Grown Program for marketing food grown within the state, as well as programs for farmland conservation and restoration (CT.gov, n.d.). This state agency has set a farmland preservation goal of 130,000 acres (52,609 ha) within the state, but the watchdog Council on Environmental Quality (2015) has cautioned that farmland loss is outpacing preservation, noting that "in reality there will not be that acreage of agricultural land remaining in the state by the end of the current century if the rate of loss continues as it has for most of the past five decades" (p. 17). Converting new land to cultivation may help the state achieve this goal for total farmland acreage in Connecticut; the results of this analysis could help to inform site selection and funding priorities, supporting the process of getting the state back on track toward its target. All towns in Connecticut must also produce a municipal plan of conservation and development every 10 years outlining community goals connected to future land use. Many towns in Windham County articulate a desire to maintain their towns' agricultural heritage and sense of place in these plans, objectives that align well with promoting municipal leasing arrangements with aspiring farmers.

These connections to state and municipal goals are especially important because of the indisputable need for financial support (through grants, loans, tax incentives, and similar mechanisms) from all levels of government if new farm operations are to be launched and sustained successfully — a reality that is not limited to Connecticut. The conversion process will 
require investment; some of the identified land is currently turf or grasslands, but the majority is forested to some degree (edge or patch forest, as all core forest areas were excluded), which would need to be cleared and the soil potentially remediated. The Connecticut Department of Agriculture has previously funded and coordinated a Farmland Restoration Program, enacted by Public Act 11-1, which has funded efforts such as removing trees, stones, and invasive plants, installing fencing, replanting vegetation, improving access roads, and more (Connecticut Department of Agriculture, 2018). Such state support would almost certainly be needed to reduce the cost burden upon institutional landowners under this scenario.

Although the majority of identified acres across the county are owned by government entities, at a town scale several of the municipalities have pockets of suitable land owned by educational organizations and nonprofit land trusts, sometimes totaling hundreds of acres. Farmer advocate organizations in these areas would do well to connect these institutional landowners with leasing guides and tools such as those created by American Farmland Trust and Land for Good (Bowell et al., 2011; Land for Good, 2012; Land for Good, n.d.). Creating templates for leasing arrangements specifically designed to meet educational or land conservation goals would be most beneficial in the towns where these institutional lands are concentrated. Were this methodology to be applied to other study areas, the percentages of land in the different institutional categories would likely differ, as would the specific resource needs for connecting these institutions to interested potential farmers.

The inclusion of agricultural footprint data and subsequent estimates of the additional capacity to feed people from the identified acres is meant to illustrate the approximate amount of food likely to be produced under this scenario, not to imply that thousands of Windham County residents will
Figure 3. Potential Increases in Agricultural Acreages by Town in Windham County, Based on Institutionally Owned Parcels after Site Suitability Analysis

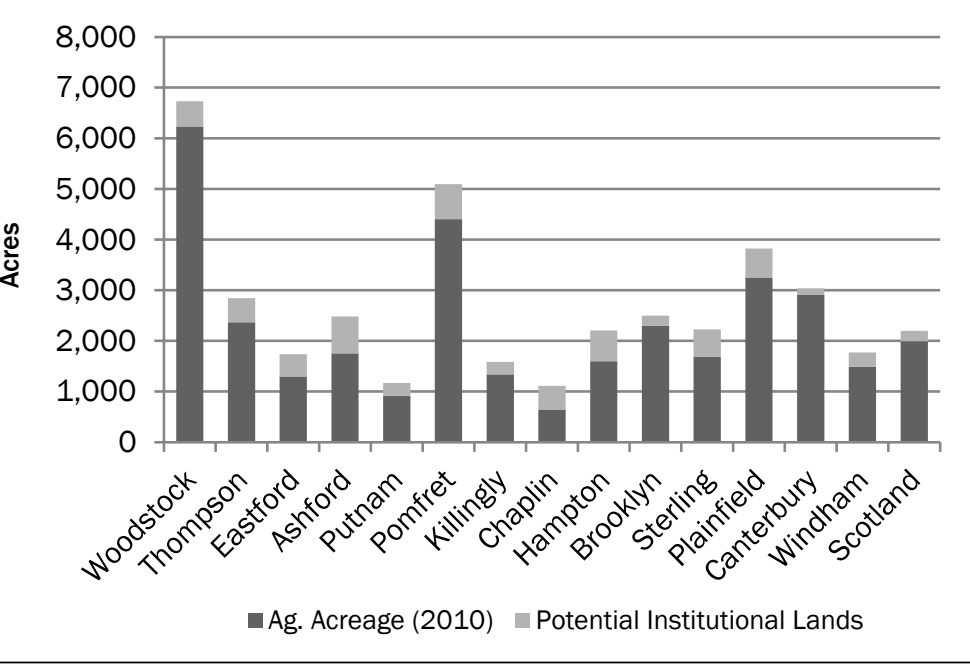

Figure 4. Ownership Category Percentages for Potential Agricultural Acreage, Based on Institutionally Owned Parcels after Site Suitability Analysis

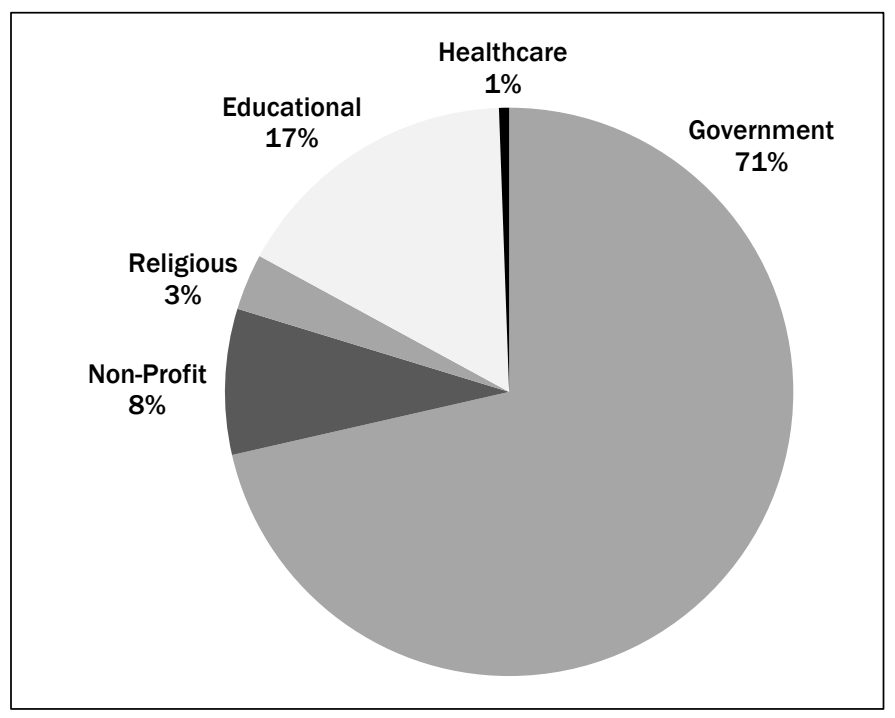

henceforth obtain all of their calories from food produced within the region. A New England Food $V$ ision calls for additional self-reliance, not complete self-sufficiency and isolation from the wider world, and no one is suggesting that New Englanders never again consume bananas, or cinnamon, or chocolate, nor should the rest of the country have to swear off New England maple syrup for good. Returning to Sen (2008) and the question of com- 
parative justice, improvement is a worthy goal even if perfection remains unattainable.

\section{Conclusion}

In the "home rule" state of Connecticut where towns hold considerable regulatory power, a perfectly unified countywide approach is unlikely. The choices of individual towns, however, can have large cumulative effects across a region, particularly if multiple complementary strategies are enacted; the same is true of the individual states that make up New England, and indeed the United States. Institutional lands - with their secure tenure, reduced development pressure, and often mission-linked ownership-may be the "lowhanging fruit" on the pathway to reaching the agricultural acreage called for by $A$ New England Food Vision, while beginning to move toward a community-level approach to sharing land access. It will not be enough, but it may be a start.

Changes in land use alone will not lead to a just and sustainable food system. Social and economic support for farmers at the federal, state, and municipal levels, expanded market opportunities, additional regional processing and distribution centers to allow the creation, packaging, and sale of value-added products, and increased public awareness of and commitment to seasonal, regional food choices will all be necessary in order to reach the goals articulated by $A$ New England Food Vision. However, without a secure and abundant agricultural land base, these other elements cannot succeed. This research project endeavors to explore options for assembling this land base in Windham County and demonstrating an adaptable model for other regions - one that marries the methodology of site suitability analyses with the value-driven goals of community land access-in the hopes that the food system of the future might avoid some of the mistakes of the past.

\section{Acknowledgments}

Many thanks to Dr. Carol Atkinson-Palombo and

Dr. Phoebe Godfrey for reviewing this manuscript. The feedback and guidance from JAFSCD's peer reviewers also improved this work considerably.

\section{References}

Agyeman, J. (2013). Introducing just sustainabilities: Policy, planning, and practice. London, UK, New York: Zed Books.

American Farmland Trust. (2015). Farmland access: The basics. Retrieved from https:// farmlandinfo.org/publications/farmland-access-the-basics/

Anderson, M. (2019). The importance of visioning in food system transformation. Journal of Agriculture, Food Systems, and Community Development, 9(Suppl. A), 55-60. https://doi.org/10.5304/jafscd.2019.09A.001

Berti, G., \& Mulligan, C. (2016). Competitiveness of small farms and innovative food supply chains: The role of food hubs in creating sustainable regional and local food systems. Sustainability, 8(7), 616. https://doi.org/10.3390/su8070616

Born, B., \& Purcell, M. (2006). Avoiding the local trap: Scale and food systems in planning research. Journal of Planning Education and Research, 26(2), 195-207. https://doi.org/10.1177/0739456X06291389

Bowell, B., Coffin, C., \& Martin, J. (2011). Farmland connections: A guide for Connecticut towns, institutions, and land trusts using or leasing farmland. Retrieved from https://farmlandinfo.org/publications/farmland-connections-a-guide-forconnecticut-towns-institutions-and-land-trusts-using-or-leasing-farmland/

Brown, S., \& Getz, C. (2011). Farmworker food insecurity and the production of hunger in California. In A. H. Alkon \& J. Agyeman (Eds.), Cultivating food justice: Race, class, and sustainability (pp. 121-146). Cambridge, MA: The MIT Press.

Carter, A. (2017). Changes on the land: Gender and the power of alternative social networks. In J. M. Williams \& E. Holt-Giménez (Eds.), Land justice: Re-imagining land, food, and the commons in the United States (pp. 76-93). Oakland, CA: Food First Books.

Colasanti, K. J. A., \& Hamm, M. W. (2010). Assessing the local food supply capacity of Detroit, Michigan. Journal of Agriculture, Food Systems, and Community Development, 1(2), 41-58. https://doi.org/10.5304/jafscd.2010.012.002

Connecticut Council on Environmental Quality. (2015). Environmental quality in Connecticut. Retrieved from https: / www.ct.gov/ceq/cwp/view.asp?a $=986 \& q=579098$ 
CT.gov [Connecticut's Official State Website]. (2018, April 11). Connecticut Department of Agriculture: Farmland restoration program brings land back into agricultural production [Press release]. Retrieved from https://portal.ct.gov/DOAG/News/2015/Farmland-Restoration-Program-Brings-Land-Back-Into-AgriculturalProduction

CT.gov. (n.d.). Connecticut Department of Agriculture. Retrieved July 15, 2019, from https://portal.ct.gov/DOAG

Donahue, B. (2003). The resettling of America. In N. Wirzba (Ed.), The essential agrarian reader: The future of culture, community, and the land (pp. 34-51). Berkeley, CA: Counterpoint.

Donahue, B., Burke, J., Anderson, M., Beal, A., Kelly, T., Lapping, M., . . Berlin, L. (2014). A New England Food Vision. Retrieved from https://foodsolutionsne.org/a-new-england-food-vision/

Erickson, D. L., Lovell, S. T., \& Méndez, V. E. (2013). Identifying, quantifying, and classifying agricultural opportunities for land use planning. Landscape and Urban Planning, 118, 29-39. https://doi.org/10.1016/j.landurbplan.2013.05.004

Feagan, R. (2007). The place of food: Mapping out the "local" in local food systems. Progress in Human Geography, 31(1), 23-42. https://doi.org/10.1177/0309132507073527

Feeding America. (2019). Map the meal gap: Food insecurity in Windham County. Retrieved from https://map.feedingamerica.org/county/2017/child/connecticut/county/windham

Gray, K. A. (2008). Community land trusts in the United States. Journal of Community Practice, 16(1), 65-78. https://doi.org/10.1080/10705420801977999

Green, J. J., Green, E. M., \& Kleiner, A. M. (2011). From the past to the present: Agricultural development and black farmers in the American South. In A. H. Alkon \& J. Agyeman (Eds.), Cultivating food justice: Race, class, and sustainability (pp. 47-64). Cambridge, MA: The MIT Press.

Griffin, T., Conrad, Z., Peters, C., Ridberg, R., \& Tyler, E. P. (2014). Regional self-reliance of the Northeast food system. Renewable Agriculture \& Food Systems, 30(4), 349-363. https://doi.org/10.1017/S1742170514000027

Hachmyer, C. (2017). Notes from a new farmer: Rent-culture, insecurity, and the need for change. In J. M. Williams \& E. Holt-Giménez (Eds.), Land justice: Re-imagining land, food, and the commons in the United States (pp.112-124). Oakland, CA: Food First Books.

Hassanein, N. (2003). Practicing food democracy: A pragmatic politics of transformation. Journal of Rural Studies, 19(1), 77-86. https://doi.org/10.1016/S0743-0167(02)00041-4

Holbrook, S. J. (1996). Manual of best management practices for agriculture: Guidelines for protecting Connecticut's water resources. Connecticut Department of Environmental Protection, Natural Resources Conservation Service. Retrieved from https://portal.ct.gov/-/media/DEEP/aquifer protection/BMPsagriculturepdf.pdf

Horrigan, L., Lawrence, R. S., \& Walker, P. (2002). How sustainable agriculture can address the environmental and human health harms of industrial agriculture. Environmental Health Perspectives, 110(5), 445-456. https://doi.org/10.1289/ehp.02110445

Kremer, P., \& DeLiberty, T. (2011). Local food practices and growing potential: Mapping the case of Philadelphia. Applied Geography, 31(4), 1252-1261. https://doi.org/10.1016/j.apgeog.2011.01.007

Land for Good. (n.d.). Build-A-Lease Tool. Retrieved from https://www.landforgood.org/lease-tool-login

Land for Good. (2012). Leasing land to farmers: A bandbook for New England land trusts, municipalities, and institutions. Retrieved from https://landforgood.org/our-work/projects/land-access-project-phase-1/lfg-leasing-land-to-farmers-forland-trusts-municipalities-handbook/

Low, S. A., Adalja, A., Beaulieu, E., Key, N., Martinez, S., Melton, A., . . . Jablonski, B. B. R. (2015). Trends in U.S. local and regional food systems (Report No. AP-068). Washington, D.C.: U.S. Department of Agriculture, Economic Research Service. Retrieved from https://www.ers.usda.gov/webdocs/publications/42805/51173_ap068.pdf

McClintock, N. (2011). From industrial garden to food desert: Demarcated devaluation in the flatlands of Oakland, California. In A. H. Alkon \& J. Agyeman (Eds.), Cultivating food justice: Race, class, and sustainability (pp. 89-120). Cambridge, MA: The MIT Press.

McClintock, N., Cooper, J., \& Khandeshi, S. (2013). Assessing the potential contribution of vacant land to urban vegetable production and consumption in Oakland, California. Landscape and Urban Planning, 111, 46-58. https://doi.org/10.1016/j.landurbplan.2012.12.009 
Meehan, J. (2014). Reinventing real estate: The community land trust as a social invention in affordable housing. Journal of Applied Social Science, 8(2), 113-133. https://doi.org/10.1177/1936724413497480

Miller, T. R., Wiek, A., Sarewitz, D., Robinson, J., Olsson, L., Kriebel, D., \& Loorbach, D. (2014). The future of sustainability science: A solutions-oriented research agenda. Sustainability Science, 9, 239-246. https://doi.org/10.1007/s11625-013-0224-6

Neumann, R. P. (2009). Political ecology: Theorizing scale. Progress in Human Geography, 33(3), 398-406. https://doi.org/10.1177/0309132508096353

Parsons, R., Ruhf, K., Stevenson, G. W., Baker, J., Bell, M., Epley, E., . . Keller, J. (2010). The farm LASTS project: Farm land access, succession, tenure and stewardship. Retrieved from https://www.uvm.edu/farmlasts/FarmLASTSResearchReport.pdf

Peters, C. J., Bills, N. L., Lembo, A. J., Wilkins, J. L., \& Fick, G. W. (2008). Mapping potential foodsheds in New York State: A spatial model for evaluating the capacity to localize food production. Renewable Agriculture and Food Systems, 24(1), 72-84. https://doi.org/10.1017/S1742170508002457

Redlin, M., \& Redlin, B. (2003). Amendment E: Rural communities and the family farm. South Dakota Law Review, 49, 787-794.

Ruhf, K. Z. (2015). Regionalism: A New England recipe for a resilient food system. Journal of Environmental Studies and Science, 5, 650-660. https://doi.org/10.1007/s13412-015-0324-y

Ruhf, K., \& Clancy, K. (2010). It takes a region: Exploring a regional food systems approach. Northeast Sustainable Agriculture Working Group. Retrieved from http://nesawg.org/sites/default/files/NESAWGRegionalFoodSystemFINALSept2010.pdf

Schnell, S. M. (2013). Food miles, local eating, and community supported agriculture: Putting local food in its place. Agriculture and Human Values, 30, 615-628. https://doi.org/10.1007/s10460-013-9436-8

Sen, A. (2008). The idea of justice. Journal of Human Development, 9(3), 331-342. https://doi.org/10.1080/14649880802236540

Sen, A. (2012). Values and justice. Journal of Economic Methodology, 19(2), 101-108. https://doi.org/10.1080/1350178X.2012.683601

The Last Green Valley, Inc. (2010). Vision 2020: The next ten years. Retrieved from https://thelastgreenvalley.org/wpcontent/uploads/2015/03/Vision-2020-The-Next-Ten-Years-in-The-Last-Green-Valley.pdf

U.S. Census Bureau. (2018). Quick facts: Windham County, Connecticut. Retrieved from https://www.census.gov/quickfacts/windhamcountyconnecticut

Zimmerer, K. S., \& Bassett, T. J. (2003). Approaching political ecology: Society, nature, and scale in human-environment studies. In K. S. Zimmerer \& T. J. Bassett (Eds.), Political Ecology: An Integrative Approach to Geography and EnvironmentDevelopment Studies (pp. 1-25). New York: The Guilford Press. 